\title{
Evaluation of nutritional compounds in new amaranth and quinoa cultivars
}

Sylvio Vicentin PALOMBINI ${ }^{1}$, Thiago CLAUS ${ }^{1}$, Swami Arêa MARUYAMA ${ }^{1}$, Aline Kirie GOHARA ${ }^{1}$, Aloisio Henrique Pereira SOUZA ${ }^{1}$, Nilson Evelázio de SOUZA², Jesuí Vergílio VISENTAINER ${ }^{1}$, Sandra Terezinha Marques GOMES ${ }^{1}$, Makoto MATSUSHITA ${ }^{1 *}$

\begin{abstract}
This study evaluated the fatty acid quantification, proximate and amino acid compositions, antioxidant activity, total phenolic compounds, vitamin E, and mineral contents of new amaranth (BRS Alegria) and quinoa (BRS Piabiru) cultivars which were produced in order to adapt these pseudocereals to the climatic conditions of central-western Brazil. They showed superior levels of protein and total lipids in comparison to their native counterparts. The lipid profile of the amaranth BRS Alegria was revealed to be better than those of other native cultivars. Quinoa BRS Piabiru presented a higher antioxidant capacity and phenolic content than the studied amaranth cultivar, but lower contents of tocopherols. All of the obtained results confirm that these new grains possess an overall amount of nutritional compounds that is better than those reported for many native counterparts of the studied samples. The employed analytical methods in this work contributed to a better understanding of the quinoa BRS Piabiru and amaranth BRS Alegria chemical compositions. Therefore, the diversity and quantity of all of the studied compounds in the samples denote the considerable importance of these grains for food science research area.
\end{abstract}

Keywords: amaranth BRS Alegria; quinoa BRS Piabiru; fatty acids.

\section{Introduction}

The pseudocereals amaranth (Amaranthus cruentus) and quinoa (Chenopodium quinoa), which are ancient Central and South American crops, are currently cultivated in regions such as Mexico, Central and South America, Africa, India, and part of China (VALENCIA-CHAMORRO, 2004). They are constantly studied by food scientists due to their high nutritional value, mainly as a result of their protein content (SCHOENLECHNER; SIEBENHANDL; BERGHOFER, 2008) and levels of essential amino acids (VALENCIA-CHAMORRO, 2004).

The oils obtained from amaranth and quinoa are also important because they contain oleic (18:1 n-9), linoleic (18:2 $\mathrm{n}-6)$ and $\alpha$-linolenic fatty acids (18:3 n-3) (RYAN et al., 2007; SCHOENLECHNER; SIEBENHANDL; BERGHOFER, 2008). According to Perini et al. (2010), linoleic and $\alpha$-linolenic fatty acids are strictly essential, because they are not produced by human de novo synthesis and must be provided by an adequate diet. The ingestion of 18:1 n-9 instead of saturated fatty acids (SFA) helps to reduce the low density lipoprotein levels in blood and, therefore, cardiovascular diseases will occur with a lesser probability (ELMADFA; KORNSTEINER, 2009).

The lipid fraction of the pseudocereals cited above also contains compounds with antioxidant capacities, such as tocopherols, which act as scavengers of lipid peroxyl radicals (LEÓN-CAMACHO; GARCÍA-GONZÁLEZ; APARICIO, 2001; RYAN et al., 2007). Part of this activity may be due to polyphenolic compounds, comprised of several classes of flavonoids and anthocyanins, as well as other phenolic constituents widely distributed at varying levels in plant- based foods (LOBO et al., 2009), which work as free radical terminators and metal ion chelators.

However, even with all of the nutritional benefits granted by lipids, proteins and antioxidant molecules, native varieties of quinoa are rejected by many human consumers. This happens because they have a bitter taste, which is associated with the presence of saponins: water-soluble and thermolabile compounds with a prominent toxicity in high doses when administered in vivo. They exist in the quinoa plant due to their efficient insecticide and anti-microbial properties (KULJANABHAGAVAD et al., 2008).

The genetic enhancement of plants in order to adapt to the geographic conditions of a certain country or region can also propitiate products without the sensorial disadvantages found in their respective native varieties. The quinoa BRS Piabiru cultivar, which is free of saponins, is an example of this. It was developed by the Brazilian Agricultural Research Corporation at unit Cerrados, Brasília City, Federal District (EMBRAPACerrados), along with the novel amaranth BRS Alegria cultivar. Both were particularly important to adapt these pseudocereals to the climatic conditions of central-western Brazil (SPEHAR; SANTOS, 2002; SPEHAR et al., 2003).

However, with the achievement of the desired geographic adaptation, a demand for deeper studies regarding their chemical compositions arose. Thus, this work is aimed at the determination of proximate composition, antioxidant activity, amino acid profile, and mineral contents of these special grains of amaranth and quinoa, and at the quantification of fatty acids and tocopherols as well.

${ }^{1}$ Department of Chemistry, State University of Maringa - UEM, Av. Colombo, 5790, CEP 87020-900, Maringa, PR, Brazil, e-mail: mmakoto@uem.br

${ }^{2}$ Food Technology Department, Federal University of Technology - UTFPR, Av. dos Pioneiros, 3131, CEP 86036-370, Londrina, PR, Brazil

${ }^{*}$ Corresponding author 


\section{Materials and methods}

\subsection{Grain sampling}

Grains of Amaranthus cruentus, BRS Alegria and Chenopodium quinoa, BRS Piabiru used were provided by EMBRAPA and processed separately.

\subsection{Proximate composition analysis}

All analyses were accomplished in five replicates. Total lipid (TL) contents in pseudocereal samples were determined according to Bligh and Dyer (1959). The moisture, ash and crude protein (CP) contents were determined using Association of Official Analytical Chemists (ASSOCIATION..., 2010) Official Methods 930.15, 942.05 and 960.52, respectively. In the CP analysis, a factor of 5.85 was used to convert nitrogen to protein percentage (CAI; CORKE; WU, 2004), and the nifext fraction was estimated by difference (between $100 \%$ and the sum of moisture, ash, crude protein, crude fiber, and total lipid content) (FAITHFULL, 2002). Crude fiber (CF) was determined according to American Oil Chemists' Society (AOCS) Method Ba 6a-05 (FIRESTONE, 1997).

\subsection{Fatty acid composition}

Fatty acid methyl esters (FAME) were prepared by total lipid methylation as described by Hartman and Lago (1973). The methyl esters were separated by gas chromatography in a Varian 3380 (USA) gas chromatography fitted with a flame ionization detector (FID) and a fused-silica capillary column $(100 \mathrm{~m} \times 0.25 \mathrm{~mm}$ id., $0.25 \mu \mathrm{m}$ cyanopropyl CP-7420 select FAME). The injector and detector temperatures were $225^{\circ} \mathrm{C}$. The column was maintained at $165^{\circ} \mathrm{C}$ for 4 minutes, followed by a heating rate of $4^{\circ} \mathrm{C} / \mathrm{min}$ to a temperature of $185^{\circ} \mathrm{C}$, which was maintained for 5 minutes, and then raised again from $185^{\circ} \mathrm{C}$ to $225^{\circ} \mathrm{C}$ at a rate of $10^{\circ} \mathrm{C} / \mathrm{min}$. The ultra-pure gas flows were of: $1.2 \mathrm{~mL} / \mathrm{min}$ (carrier gas - hydrogen), $30 \mathrm{~mL} / \mathrm{min}$ (make-up gas - nitrogen), $300 \mathrm{~mL} / \mathrm{min}$ (synthetic air) and $30 \mathrm{~mL} / \mathrm{min}$ (hydrogen flame gas), with a split injection ratio of $1 / 100$.

For the fatty acid identification, the retention times were compared to those obtained with standard methyl esters (Sigma, USA). Quantification of fatty acids was performed through the use of tricosanoic acid methyl ester (Sigma, USA) as an internal standard, according to Joseph and Ackman (1992). The software Star 5.0 (Varian, USA) was employed to determine peak areas through the internal standard method.

\subsection{Tocopherol content determination}

The analyte extraction was accomplished according to Delgado-Zamarreño et al. (2004). The fractions of tocopherols were separated by High Performance Liquid Chromatography in a Varian 335 (USA) chromatograph fitted with a diode array detector and C18 reversed-phase column (microsorb, $250 \mathrm{~mm} \times 4.6 \mathrm{~mm}$ id., $5 \mu \mathrm{m}$ ) with an isocratic elution; the solvent flow rate was maintained at $0.80 \mathrm{~mL} / \mathrm{min}$ with column temperature of $25^{\circ} \mathrm{C}$ and a backpressure of approximately 10 bar.
The mobile phase consisted of methanol: dichloromethane at a ratio of $85: 15(\mathrm{v} / \mathrm{v})$. The UV detection wavelength was set at $292 \mathrm{~nm}$. Tocopherols were identified by comparison of the retention times with those of authentic standards from Sigma (USA). Peak areas were determined using the software Star 6.0 (Varian, USA) through the external standard method.

\subsection{Antioxidant capacity analysis}

The extraction of antioxidant compounds needed for the analysis of free radical scavenging ability on 1,1-diphenyl-2picrylhydrazyl (DPPH) and total phenolic compounds content was carried out with $10 \mathrm{~g}$ of each ground grain, $100 \mathrm{~mL}$ of methanol (1:10; w:v) and stirring for 4 hours with a magnetic bar.

The antioxidant capacity of the grain extracts was evaluated through their free radical-scavenging activity on the 1,1-diphenyl-2-picrylhydrazyl radical method described by Nsimba, Kikuzaki and Konishi (2008). Different aliquots of extract solutions prepared by adding $20 \mathrm{mg}$ of methanolic extract and $10 \mathrm{~mL}$ of methanol were mixed with $2 \mathrm{~mL}$ of methanolic solution containing the DPPH radical $(0.2 \mathrm{mM})$. The mixture was shaken vigorously and left to stand for $30 \mathrm{~min}$ in the dark before measuring the absorbance at $517 \mathrm{~nm}$ against a methanol blank without DPPH. The radical scavenging activity was calculated as follows: $\mathrm{I} \%=\left[\left(\mathrm{Abs}_{\mathrm{DPPH}}-\mathrm{Abs}_{\text {Sample }}\right) / \mathrm{Abs}_{\mathrm{DPPH}}\right]$ $\times 100$, where $\mathrm{Abs}_{\mathrm{DPPH}}$ is the absorbance of the DPPH solution without extracts, and $\mathrm{Abs}_{\text {Sample }}$ is the absorbance of the sample solution. The concentration providing $50 \%$ inhibition $\left(\mathrm{IC}_{50}\right)$ was calculated graphically using a calibration curve in the linear range by plotting the extract concentration versus the corresponding scavenging effect.

Total phenolic compounds content was determined according to the Shahidi and Naczk (1995) method. A $0.25 \mathrm{~mL}$ aliquot of extract solution $(2.5 \mathrm{mg} / \mathrm{mL}$ in methanol) was mixed with $0.25 \mathrm{~mL}$ of Folin-Ciocalteu's reagent previously diluted with water $(1: 1 ; \mathrm{v} / \mathrm{v}), 0.5 \mathrm{~mL}$ of a saturated sodium carbonate solution and $4 \mathrm{~mL}$ of water. The mixture was allowed to rest at room temperature for $25 \mathrm{~min}$ and then was centrifuged at $3800 \times g$ for $10 \mathrm{~min}$ the supernatant absorbance was measured at $725 \mathrm{~nm}$ using a spectrophotometer (Cary Win UV 50, Varian). Gallic acid (GA) was used as a standard and the results are expressed as Gallic acid equivalent (mg GAE/g).

\subsection{Amino acid composition}

The amino acid profiles were determined according to the method proposed by White, Hart and Fry (1986). Samples were hydrolyzed with $\mathrm{HCl} 6 \mathrm{~mol} / \mathrm{L}$ with phenol for $24 \mathrm{~h}$ to obtain free amino acids. These free amino acids were derivatized with phenylisothiocyanate (PITC), as proposed by Hagen, Frost and Augustin (1989). The derivatives were separated on HPLC unit, using a reverse-phase C18 $(250 \times 4.6 \mathrm{~mm} ; 5 \mu \mathrm{m}$ particle size) column. The solvent system consisted of two eluents: eluent A (buffer solution of sodium acetate, acetonitrile, and triethylamine) and eluent B (acetonitrile 60\% (v/v)). Elution was performed at a flow rate of $1 \mathrm{~mL} / \mathrm{min}$, starting with $0 \%$ of eluent B until 5 min and employing a gradient to obtain $22.5 \%$ 
$\mathrm{B}$ at 10 minutes, $60 \% \mathrm{~B}$ at $20 \mathrm{~min}$, and $100 \% \mathrm{~B}$ at 28 minutes. Detection was achieved with a UV-VIS source at a wavelength of $254 \mathrm{~nm}$. The amino acid quantification was accomplished through the inclusion of $\alpha$-aminobutyric acid as an internal standard.

\subsection{Minerals}

The content of minerals were determined in an atomic absorption spectrophotometer AA240FS (Varian, USA). The digestion of the sample and the minerals iron $(\mathrm{Fe})$, copper $(\mathrm{Cu})$, manganese $(\mathrm{Mn})$, sodium $(\mathrm{Na})$, calcium $(\mathrm{Ca})$, magnesium $(\mathrm{Mg})$, potassium $(\mathrm{K})$, and phosphorus $(\mathrm{P})$ were quantified according to AOAC Official Method 985.35 (ASSOCIATION..., 2010). Standard solutions and analytical curves were used for each element and the results were expressed in milligrams of the mineral per $100 \mathrm{~g}$ of the product.

\subsection{Statistical analysis}

The results were submitted to variance analysis (ANOVA) and means were compared using the Tukey test through the Statistica program, version 7.0. The significance level used for rejection of the null hypothesis was $5 \%(\mathrm{p}<0.05)$. Correlation coefficients $(\mathrm{R})$ used to determine the relationship between antioxidant activity measured and total phenolic content were calculated by using Microsoft Office Excel software, version 2007.

\section{Results and discussion}

The cultivar BRS Alegria showed a crude protein level which was greater $(20.92 \pm 0.23 \%)$ in relation to BRS Piabiru $(16.41 \pm 0.15 \%)$. With regards to quinoa, the obtained values were slightly better than the $14.8 \%$ and $15.7 \%$ described by Wright et al. (2002) for sweet and bitter quinoa, respectively. These results enforce the fact that the genetically-enhanced cultivars can be better sources of lipids and proteins in relation to other varieties.

The pseudocereal cultivars which were analyzed in this work showed similar quantities of total lipids (8.68 \pm 0.39 and $9.71 \pm 0.57 \%$ for amaranth and quinoa, respectively). These values were greater than the $7.2 \%$ described by Cai, Corke and $\mathrm{Wu}$ (2004) for common amaranth grains.

The detected amounts of ash $(3.42 \pm 0.06 \%$ for amaranth and $3.03 \pm 0.89 \%$ for quinoa) and crude fiber $(2.17 \pm 0.01 \%$ and $1.92 \pm 0.22 \%$ for amaranth and quinoa, respectively) did not show a significant difference between themselves $(\mathrm{p}<0.05)$. However, quinoa showed greater values for the Nifext fraction $(68.92 \pm 1.09 \%)$ in relation to amaranth $(64.80 \pm 0.46 \%)$.

Regarding the lipid profile (Table 1), amaranth had higher concentrations of saturated fatty acids (SFA) than quinoa. However, the latter showed greater contents of polyunsaturated fatty acids (PUFA), such as linoleic and linolenic acids, resulting in an increase of its PUFA/SFA ratio. Despite having higher total amounts of omega 6 and omega 3 fatty acids, quinoa presented a lower value for the $n-6 / n-3$ ratio, which was better than that
Table 1. Fatty acids composition $(\mathrm{mg} / \mathrm{g} \mathrm{TL})^{\mathrm{a}}$ of amaranth and quinoa grains and ratios n-6/n-3 and PUFA/SFA.

\begin{tabular}{ccc}
\hline Fatty acid & Amaranth & Quinoa \\
\hline $14: 0$ & $1.79 \pm 0.02^{\mathrm{a}}$ & $1.66 \pm 0.10^{\mathrm{a}}$ \\
$16: 0$ & $155.89 \pm 0.37^{\mathrm{a}}$ & $93.36 \pm 0.48^{\mathrm{b}}$ \\
$16: 1 \mathrm{n}-7$ & $2.87 \pm 0.17$ & n.d. \\
$17: 1$ & $5.42 \pm 0.11^{\mathrm{a}}$ & $1.89 \pm 0.12^{\mathrm{b}}$ \\
$18: 0$ & $21.85 \pm 0.48^{\mathrm{a}}$ & $6.38 \pm 0.80^{\mathrm{b}}$ \\
$18: 1 \mathrm{n}-9$ & $238.29 \pm 4.78^{\mathrm{a}}$ & $231.95 \pm 0.82^{\mathrm{a}}$ \\
$18: 1 \mathrm{n}-7$ & $8.72 \pm 0.16^{\mathrm{a}}$ & $8.72 \pm 0.03^{\mathrm{a}}$ \\
$18: 2 \mathrm{n}-6$ & $289.25 \pm 6.06^{\mathrm{a}}$ & $516.53 \pm 0.56^{\mathrm{a}}$ \\
$18: 3 \mathrm{n}-3$ & $6.92 \pm 0.22^{\mathrm{b}}$ & $28.73 \pm 0.10^{\mathrm{a}}$ \\
$18: 3 \mathrm{n}-6$ & $5.32 \pm 0.15^{\mathrm{b}}$ & $4.54 \pm 0.44^{\mathrm{a}}$ \\
$20: 0$ & $1.99 \pm 0.03^{\mathrm{a}}$ & $13.52 \pm 0.84^{\mathrm{a}}$ \\
$22: 0$ & $2.49 \pm 0.09^{\mathrm{b}}$ & $5.80 \pm 0.19^{\mathrm{a}}$ \\
$22: 1 \mathrm{n}-9$ & $\mathrm{n} . \mathrm{d} \cdot \mathrm{g}$ & $12.74 \pm 0.19$ \\
$22: 2 \mathrm{n}-6$ & $21.11 \pm 0.67$ & $\mathrm{n} . \mathrm{d}$. \\
$24: 0$ & $\mathrm{n} . \mathrm{d}$. & $2.16 \pm 0.06$ \\
SFA & $185.20 \pm 3.76^{\mathrm{a}}$ & $122.89 \pm 1.26^{\mathrm{b}}$ \\
MUFA & $256.77 \pm 5.15^{\mathrm{a}}$ & $255.30 \pm 0.84^{\mathrm{a}}$ \\
PUFA & $322.89 \pm 4.60^{\mathrm{b}}$ & $549.81 \pm 0.87^{\mathrm{a}}$ \\
n-6 & $315.93 \pm 4.43^{\mathrm{b}}$ & $521.08 \pm 0.79^{\mathrm{a}}$ \\
n-3 & $6.96 \pm 0.20^{\mathrm{b}}$ & $28.73 \pm 0.10^{\mathrm{a}}$ \\
n-6/n-3 & $45.42 \pm 0.82^{\mathrm{a}}$ & $18.13 \pm 0.05^{\mathrm{b}}$ \\
PUFA/SFA & $1.74 \pm 0.02^{\mathrm{b}}$ & $4.47 \pm 0.05^{\mathrm{a}}$ \\
\hline & &
\end{tabular}

${ }^{2}$ Results expressed as mean \pm standard deviation for analysis in five replicates. Means followed by different letters in the same line are significantly different by Tukey's test $(p>0.05)$. ${ }^{\text {SSFA }}=$ sum of saturated fatty acids. ${ }^{c} \mathrm{MUFA}=$ sum of monounsaturated fatty acids. ${ }^{\mathrm{d}} \mathrm{PUFA}=$ sum of polyunsaturated fatty acids. ${ }^{\mathrm{e}} \mathrm{n}-6=$ sum of omega 6 fatty acids. ${ }_{\mathrm{n}} \mathrm{n}-3=$ sum of omega 3 fatty acids. ${ }^{\text {nn.d. }}=$ not detected.

determined in the BRS Alegria amaranth cultivar. An n-6/n-3 ratio of between $1: 1$ and 2:1 is highly recommended, because high ratios may result in allergy or anti-inflammatory disorders, and the irregular proliferation of cells (SIMOPOULOS, 2011).

The amaranth cultivar investigated in this work had a concentration of oleic acid (31.33\%) greater than that reported by Martirosyan et al. (2007) (22.69\%). It also had a linoleic acid content (38.02\%) lower than the $48 \%$ described by the same author cited above, and a similar quantity of a-linolenic acid (18:3n-3) in relation to other studies (LEÓN-CAMACHO; GARCÍA-GONZÁLEZ; APARICIO, 2001). The opposite was observed for the quinoa BRS Piabiru, with a greater concentration of 18:2n-6 and lower quantities of 18:1n-9 and 18:3n-3 than those found by Ryan et al. (2007). However, this determined oleic acid amount was greater than the $20.84 \%$ reported by Wood et al. (1993).

Amaranth had a similar total concentration of saturated fatty acids (SFA) $(24.21 \%)$ when compared to the values reported in previous studies (LEÓN-CAMACHO; GARCÍAGONZÁLEZ; APARICIO, 2001). The total SFA amount for quinoa was also close to other studies (RYAN et al., 2007; WOOD et al., 1993).

In relation to the total PUFA content of the studied BRS Alegria, its value was higher than that reported by León- 
Camacho, García-González and Aparicio (2001) and lower than that determined by Martirosyan et al. (2007), while the BRS Piabiru had a value similar to those of other studies (RYAN et al., 2007; WOOD et al., 1993). The PUFA/SFA ratio found for the amaranth was similar to the data obtained in previous studies (LEÓN-CAMACHO; GARCÍA-GONZÁLEZ; APARICIO, 2001; MARTIROSYAN et al., 2007). Quinoa also presented values similar to other studies (RYAN et al., 2007; WOOD et al., 1993). Furthermore, it can be pointed out that the high PUFA/SFA ratios found in the cultivars investigated are higher than the minimum value required for healthy nutrition (LONDON, 1994).

Both of the studied grains presented similar amino acid compositions (Table 2), with higher concentrations of the essential amino acids leucine, lysine, and phenylalanine.

Concerning mineral composition (Table 3), the major mineral in both grains was potassium, which is an important chemical element that helps to prevent muscle weakness, respiratory insufficiency, and hypotension in humans (HATHCOCK, 2004).

Table 2. Amino acid composition for amaranth and quinoa grains.

\begin{tabular}{lcc}
\hline \multirow{2}{*}{ Amino acid } & \multicolumn{2}{c}{ g/100 g grain } \\
\cline { 2 - 3 } & Amaranth & Quinoa \\
\hline Alanine & 0.53 & 0.53 \\
Arginine & 1.47 & 1.20 \\
Aspartic Acid & 1.22 & 1.07 \\
Glycine & 1.38 & 0.88 \\
Isoleucine & 0.55 & 0.48 \\
Leucine & 0.86 & 0.84 \\
Glutamic Acid & 2.51 & 1.89 \\
Lysine & 0.83 & 0.70 \\
Cystine & 0.19 & 0.15 \\
Methionine & 0.34 & 0.31 \\
Phenylalanyne & 0.61 & 0.50 \\
Tyrosine & 0.54 & 0.41 \\
Threonine & 0.43 & 0.37 \\
Proline & 0.69 & 0.56 \\
Valine & 0.60 & 0.57 \\
Histidine & 0.38 & 0.36 \\
Serine & 0.88 & 0.57 \\
\hline
\end{tabular}

Results expressed as mean \pm standard deviation for analysis in five replicates.

Table 3. Minerals in Amaranth and Quinoa grains.

\begin{tabular}{ccc}
\hline & Amaranth & Quinoa \\
\cline { 2 - 3 } $\mathrm{Fe}$ & \multicolumn{2}{c}{$\mathrm{mg} / 100 \mathrm{~g}$} \\
$\mathrm{Cu}$ & $29.35 \pm 0.60$ & $10.28 \pm 0.33$ \\
$\mathrm{Mn}$ & $1.25 \pm 0.03$ & $1.55 \pm 0.05$ \\
$\mathrm{Na}$ & $4.07 \pm 0.08$ & $3.41 \pm 0.11$ \\
$\mathrm{Ca}$ & $4.14 \pm 0.08$ & $7.31 \pm 0.23$ \\
$\mathrm{Mg}$ & $425.14 \pm 5.74$ & $108.41 \pm 3.47$ \\
$\mathrm{~K}$ & $770.15 \pm 15.61$ & $298.24 \pm 9.55$ \\
$\mathrm{P}$ & $55.59 \pm 1.13$ & $935.70 \pm 29.98$ \\
\hline
\end{tabular}

Results expressed as mean \pm standard deviation for analysis in five replicates.
Tables 4 and 5 present the nutritional contribution (INSTITUTE..., 2005) of amaranth and quinoa grains for different age groups, based on the value of a portion of $100 \mathrm{~g}$. Regarding the trace minerals, copper was present in an amount

Table 4. Contribution in percentage of Dietary Reference Intake (DRI) of minerals in amaranth grains.

\begin{tabular}{|c|c|c|c|c|c|c|c|c|}
\hline Amaranth & $\mathrm{Fe}$ & $\mathrm{Cu}$ & $\mathrm{Mn}$ & $\mathrm{Na}$ & $\mathrm{Ca}$ & $\mathrm{Mg}$ & $\mathrm{K}$ & $\mathrm{P}$ \\
\hline \multicolumn{9}{|l|}{ Males } \\
\hline $9-13 y$ & 24.46 & 180.00 & 214.21 & 0.28 & 21.78 & 177.17 & 1.71 & 4.45 \\
\hline $14-18 y$ & 19.57 & 141.57 & 185.00 & 0.28 & 21.78 & 103.71 & 1.64 & 4.45 \\
\hline $19-30 y$ & 19.57 & 140.00 & 176.96 & 0.28 & 28.31 & 106.30 & 1.64 & 7.94 \\
\hline $31-50 y$ & 19.57 & 140.00 & 176.96 & 0.28 & 28.31 & 101.24 & 1.64 & 7.94 \\
\hline $51-70 y$ & 19.57 & 140.00 & 176.96 & 0.32 & 28.31 & 101.24 & 1.64 & 7.94 \\
\hline$>70 y$ & 19.57 & 140.00 & 176.96 & 0.35 & 23.60 & 101.24 & 1.64 & 7.94 \\
\hline \multicolumn{9}{|l|}{ Females } \\
\hline $9-13 y$ & 24.46 & 180.00 & 254.38 & 0.28 & 21.78 & 177.17 & 1.71 & 4.45 \\
\hline $14-18 y$ & 19.57 & 141.57 & 254.38 & 0.28 & 21.78 & 118.11 & 1.64 & 4.45 \\
\hline $19-30 y$ & 19.57 & 140.00 & 226.11 & 0.28 & 28.31 & 137.16 & 1.64 & 7.94 \\
\hline $31-50 y$ & 19.57 & 140.00 & 226.11 & 0.28 & 28.31 & 132.88 & 1.64 & 7.94 \\
\hline $51-70 y$ & 19.57 & 140.00 & 226.11 & 0.32 & 23.60 & 132.88 & 1.64 & 7.94 \\
\hline$>70 y$ & 19.57 & 140.00 & 226.11 & 0.35 & 23.60 & 132.88 & 1.64 & 7.94 \\
\hline \multicolumn{9}{|l|}{ Pregnancy } \\
\hline $14-18 y$ & 13.34 & 126.00 & 203.50 & 0.28 & 21.78 & 106.30 & 1.64 & 4.45 \\
\hline $19-30 y$ & 13.34 & 126.00 & 203.50 & 0.28 & 28.31 & 121.49 & 1.64 & 7.94 \\
\hline $31-50 y$ & 13.34 & 126.00 & 203.50 & 0.28 & 28.31 & 118.11 & 1.64 & 7.94 \\
\hline \multicolumn{9}{|l|}{ Lactation } \\
\hline $14-18 y$ & 10.12 & 96.92 & 156.54 & 0.28 & 21.78 & 118.11 & 1.51 & 4.45 \\
\hline $19-30 y$ & 10.12 & 96.92 & 156.54 & 0.28 & 28.31 & 137.16 & 1.51 & 7.94 \\
\hline $31-50 y$ & 10.12 & 96.92 & 156.54 & 0.28 & 28.31 & 132.88 & 1.51 & 7.94 \\
\hline
\end{tabular}

Table 5. Contribution in percentage of Dietary Reference Intake (DRI) of minerals in quinoa grains.

\begin{tabular}{ccccccccc}
\hline Quinoa & $\mathrm{Fe}$ & $\mathrm{Cu}$ & $\mathrm{Mn}$ & $\mathrm{Na}$ & $\mathrm{Ca}$ & $\mathrm{Mg}$ & $\mathrm{K}$ & $\mathrm{P}$ \\
\hline Males & & & & & & & & \\
9-13y & 8.57 & 66.43 & 179.47 & 0.49 & 8.34 & 124.27 & 20.79 & 3.67 \\
14-18y & 6.85 & 52.25 & 155.00 & 0.49 & 8.34 & 72.74 & 19.91 & 3.67 \\
19-30y & 6.85 & 51.67 & 148.26 & 0.49 & 10.84 & 74.56 & 19.91 & 6.55 \\
31-50y & 6.85 & 51.67 & 148.26 & 0.49 & 10.84 & 71.01 & 19.91 & 6.55 \\
51-70y & 6.85 & 51.67 & 148.26 & 0.56 & 10.84 & 71.01 & 19.91 & 6.55 \\
>70y & 6.85 & 51.67 & 148.26 & 0.61 & 9.03 & 71.01 & 19.91 & 6.55 \\
Females & & & & & & & & \\
9-13y & 8.57 & 66.43 & 213.13 & 0.49 & 8.34 & 124.27 & 20.79 & 3.67 \\
14-18y & 6.85 & 52.25 & 213.13 & 0.49 & 8.34 & 82.84 & 19.91 & 3.67 \\
19-30y & 6.85 & 51.67 & 189.44 & 0.49 & 10.84 & 96.21 & 19.91 & 6.55 \\
31-50y & 6.85 & 51.67 & 189.44 & 0.49 & 10.84 & 93.20 & 19.91 & 6.55 \\
51-70y & 6.85 & 51.67 & 189.44 & 0.56 & 9.03 & 93.20 & 19.91 & 6.55 \\
>70y & 6.85 & 51.67 & 189.44 & 0.61 & 9.03 & 93.20 & 19.91 & 6.55 \\
Pregnancy & & & & & & & & \\
14-18y & 4.67 & 46.50 & 170.50 & 0.49 & 8.34 & 74.56 & 19.91 & 3.67 \\
19-30y & 4.67 & 46.50 & 170.50 & 0.49 & 10.84 & 85.21 & 19.91 & 6.55 \\
31-50y & 4.67 & 46.50 & 170.50 & 0.49 & 10.84 & 82.84 & 19.91 & 6.55 \\
Lactation & & & & & & & & \\
14-18y & 3.54 & 35.77 & 131.15 & 0.49 & 8.34 & 82.84 & 18.35 & 3.67 \\
19-30y & 3.54 & 35.77 & 131.15 & 0.49 & 10.84 & 96.21 & 18.35 & 6.55 \\
31-50y & 3.54 & 35.77 & 131.15 & 0.49 & 10.84 & 93.20 & 18.35 & 6.55 \\
\hline & & & & & & & & \\
\hline
\end{tabular}


Table 6. Tocopherol content, $\mathrm{IC}_{50}$ values and total phenolic content of amaranth and quinoa grains $s^{\mathrm{a}}$.

\begin{tabular}{lcc}
\hline & Amaranth & Quinoa \\
\hline$\alpha$-tocopherol ${ }^{\mathrm{b}}$ & $1.15 \pm 0.01^{\mathrm{a}}$ & $1.16 \pm 0.01^{\mathrm{a}}$ \\
$\beta+\gamma$ tocoferol $^{\mathrm{b}}$ & $1.35 \pm 0.01^{\mathrm{a}}$ & $1.08 \pm 0.03^{\mathrm{b}}$ \\
${\text { DPPH }\left(\mathrm{IC}_{50}{ }^{\mathrm{c}}\right.}^{\text {Total Phenolic Content }}{ }^{\mathrm{d}}$ & $638.67 \pm 67.70^{\mathrm{a}}$ & $313.25 \pm 10.68^{\mathrm{b}}$ \\
\hline
\end{tabular}

aResults expressed as mean \pm standard deviation for analysis in five replicates. Means followed by different letters in the same line are significantly different by Tukey's test ( $p>0.05$ ). ${ }^{b}$ Tocopherols in $\mathrm{mg} / 100 \mathrm{~g} .{ }^{\circ} \mathrm{DPPH}\left(\mathrm{IC}_{50}\right)$ in $\mu \mathrm{g} / \mathrm{mL} .{ }^{\mathrm{d}}$ Total Phenolic Content in $\mathrm{mgGAE} / 100 \mathrm{~g}$

above than the established dietary reference intake (DRI) values for amaranth grains, while the same was observed for manganese for both grains. Between macrominerals, the magnesium showed a greater value than that established by DRI. However, these values are not sufficient to cause toxicity, because it does not exceed the tolerable daily intake levels (INSTITUTE..., 2005). As amaranth and quinoa have good levels of minerals, their consumption may reduce the risk of coronary heart disease, anemia, osteoporosis and prostate cancer, by maintaining the immune system (HATHCOCK, 2004).

The grains had similar values $(\mathrm{p}<0.05)$ of $\alpha$-tocopherol (Table 6) but the sums of $\beta$ - and $\gamma$-tocopherols were different $(p>0.05)$, with amaranth BRS Alegria presenting the highest values. The $\alpha$-tocopherol concentration and the sum of $\beta$ - and $\gamma$-tocopherols detected in the studied cultivar are in accordance with the range $(0.297-1.565 \mathrm{mg} / 100 \mathrm{~g}$ for $\alpha$-tocopherol and $0.69-2.05 \mathrm{mg} / 100 \mathrm{~g}$ for the sum of $\beta$ - and $\gamma$-tocopherols) proposed by Lehmann, Putnam and Qureshi (1994). Quinoa BRS Piabiru presented lower values of a-tocopherol than reported in previous studies (RYAN et al., 2007), and the sum of $\beta$ and $\gamma$ tocopherols was also lower than that found by RYAN et al. (2007).

The lowest concentration necessary for 50\% inhibition of DPPH (Table 6) was obtained in quinoa grains, while amaranth grains presented worse results. Nsimba, Kikuzaki and Konishi (2008) studied different ecotypes and extracts of quinoa and amaranth grains and found that ethyl acetate fractions had $\mathrm{IC}_{50}$ values of approximately $300 \mu \mathrm{g} / \mathrm{mL}$ for them, which was similar to those found in this study.

The total phenolic content (TPC) found in this study was higher in quinoa than in amaranth grains. The correlation between TPC and $\mathrm{IC}_{50}$ values was also determined. A good correlation between TPC and antioxidant capacity was observed $(r=0.871)$. This result suggests that the phenolic compounds of the analyzed grains are probably responsible for their antioxidant activity.

\section{Conclusions}

The cultivars of amaranth and quinoa analyzed in this study showed superior levels of protein and total lipids in comparison to their native counterparts. The lipid profile of the amaranth BRS Alegria was revealed to be better than those of other native cultivars. The analyzed quinoa variety presented a higher antioxidant capacity and phenolic content than the studied amaranth cultivar, but lower contents of tocopherols. All of the obtained results confirm that these genetically-enhanced grains possess an overall amount of bioactive compounds that is better than those reported for many native counterparts of the studied samples. The employed analytical methods in this work contributed to a better understanding of the quinoa BRS Piabiru and amaranth BRS Alegria chemical compositions. Therefore, the diversity and quantity of all of the studied compounds in the samples denote the considerable importance of these grains for food, and more specifically, pseudocereal research area.

\section{Acknowledgments}

The authors would like to thank Capes, $\mathrm{CNPq}$, and the Araucaria Foundation for financial support and the Brazilian Agricultural Research Corporation - unit Cerrados, Brasília, Federal District, Brazil, for the donation of grains.

\section{References}

ASSOCIATION OF OFFICIAL ANALYTICAL CHEMISTS - AOAC. Official Methods of Analysis. 18th ed. Washington: AOAC, 2010.

BLIGH, E. G.; DYER, W. J. A rapid method of total lipid extraction and purification. Canadian Journal of Biochemistry and Physiology, v. 37, p. 911-917, 1959. PMid:13671378. http://dx.doi.org/10.1139/ 059-099

CAI, Y. Z.; CORKE, H.; WU, H. X. Amaranth. In: WRIGLEY, C.; CORKE, H.; WALKER, C. E. (Eds.). Encyclopedia of Grain Science. North Ryde: Academic Press, 2004. p. 1-10. http://dx.doi. org/10.1016/B0-12-765490-9/00001-X

DELGADO-ZAMARREÑO, M. M. et al. Pressurized liquid extraction prior to liquid chromatography with electrochemical detection for the analysis of vitamin $\mathrm{E}$ isomers in seeds and nuts. Journal of Chromatography A, v. 1056, p. 249-252, 2004. PMid:15595558. http://dx.doi.org/10.1016/j.chroma.2004.09.033

ELMADFA, I.; KORNSTEINER, M. Fats and fatty acid requirement for adults. Annals of Nutrition \& Metabolism, v. 55, p. 56-75, 2009. PMid:19752536. http://dx.doi.org/10.1159/000228996

FAITHFUlL, N. T. Acid-digestion, Ashing and Extraction Procedures. In: FAITHFULL, N. T. (Ed.). Methods in agricultural chemical analysis. Bristol: CABI, 2002. p. 40-41. http://dx.doi. org/10.1079/9780851996080.0030

FIRESTONE, D. Official Methods and Recommended Practices of the American Oil Chemists' Society. Champaign: AOCS Press, 1997.

HAGEN, S. R.; FROST, B.; AUGUSTIN, J. Pre-column phenylisothiocyanate derivatization and liquid-chromatography of amino acids in food. Journal of the Association of Official Analytical Chemists, v. 72, p. 912-916, 1989. PMid:2592313.

HARTMAN, L.; LAGO, R. C. A. Rapid preparation of fatty acid methyl esters from lipids. Laboratory Practice, v. 22, p. 475-476, 1973. PMid:4727126.

HATHCOCK, J. N. Vitamin and mineral safety. 2nd ed. Washington: Council for Responsible Nutrition, 2004.

INSTITUTE OF MEDICINE OF THE NATIONAL ACADEMIES. Dietary reference intakes for energy, carbohydrate, fiber, fat, fatty acids, cholesterol, protein, and amino acids. Washington: The National Academies Press, 2005.

JOSEPH, J. D.; ACKMAN, R. G. Capillary column gas chromatography method for analysis of encapsulated fish oil and fish oil ethyl 
esters: Collaborative study. Journal of AOAC International, v. 75, p. 488-506, 1992.

KULJANABHAGAVAD, T. et al. Triterpene saponins from Chenopodium quinoa Willd. Phytochemistry, v. 69, p. 19191926, 2008. PMid:18452959. http://dx.doi.org/10.1016/j. phytochem.2008.03.001

LEHMANN, J.; PUTNAM, D.; QURESHI, A.; Vitamin E isomers in grain amaranths (Amaranthus spp.). Lipids, v. 29, p. 177-181, 1994. http://dx.doi.org/10.1007/BF02536726

LEÓN-CAMACHO, M.; GARCÍA-GONZÁLEZ, D. L.; APARICIO, R. A detailed and comprehensive study of amaranth (Amaranthus cruentus L.) oil fatty profile. European Food Research and Technology, v. 213, p. 349-355, 2001. http://dx.doi.org/10.1007/ s002170100340

LOBO, A. P. et al. Phenolic and antioxidant composition of cider. Journal of Food Composition and Analysis, v. 22, p. 644-648, 2009. http://dx.doi.org/10.1016/j.jfca.2009.03.008

LONDON. Department of Health. Nutritional aspects of cardiovascular disease. Report of the cardiovascular review group of the committee on medical aspects of food policy. London: HMSO, 1994. v. 46.

MARTIROSYAN, D. M. et al. Amaranth oil application for coronary heart disease and hypertension. Lipids in Health and Disease, v. 6, p. 1-12, 2007. PMid:17207282 PMCid:1779269. http://dx.doi. org/10.1186/1476-511X-6-1

NSIMBA, R. Y.; KIKUZAKI, H.; KONISHI, Y. Antioxidant activity of various extracts and fractions of Chenopodium quinoa and Amaranthus spp. seeds. Food Chemistry, v. 106, p. 760-766, 2008. http://dx.doi.org/10.1016/j.foodchem.2007.06.004

PERINI, J. A. L. et al. Omega-3 and omega-6 polyunsaturated fatty acids: metabolism in mammals and immune response. Brazilian Journal of Nutrition, v. 23, p. 1075-1086, 2010.

RYAN, E. et al. Phytosterol, squalene, tocopherol content and fatty acid profile of selected seeds, grains, and legumes. Plant Foods for Human Nutrition, v. 62, p. 85-91, 2007. PMid:17594521. http:// dx.doi.org/10.1007/s11130-007-0046-8
SCHOENLECHNER, R.; SIEBENHANDL, S.; BERGHOFER, E. Pseudocereals. In: ARENDT, E. K.; BELLO, F. D. (Eds.). Gluten-Free cereal products and beverages. London, San Diego: Elsevier, 2008. p. 149-176. http://dx.doi.org/10.1016/B978-012373739-7.50009-5

SHAHIDI, F.; NACZK, M. Methods of analysis and quantification of phenolic compounds. Food phenolics: Sources, chemistry, effects and applications. Lancaster: Technomic Publishing Company, 1995. p. 287-293.

SIMOPOULOS, A. P. Evolutionary aspects of diet: The omega-6/ omega-3 ratio and the brain. Molecular Neurobiology, v. 44, p. 203-215, 2011. PMid:21279554. http://dx.doi.org/10.1007/ s12035-010-8162-0

SPEHAR, C. R.; SANTOS, R. L. B. Quinoa BRS Piabiru: alternative for diversification of cropping systems. Brazilian Journal of Agricultural Research, v. 37, p. 889-893, 2002.

SPEHAR, C. R. et al. Amaranth BRS Alegria: alternative for diversification of cropping systems. Brazilian Journal of Agricultural Research, v. 38, p. 659-663, 2003.

VALENCIA-CHAMORRO, S. A.; Quinoa. In: WRIGLEY, C.; CORKE, H.; WALKER, C. E. (Eds.). Encyclopedia of Grain Science. North Ryde: Academic Press, 2004. p. 918-925. http://dx.doi.org/10.1016/ B0-12-765490-9/00135-X

WHITE, J. A.; HART, R. J.; FRY, J. C. An evaluation of the waters picotag system for the amino acid analysis of food Materials. Journal of Automatic Chemistry, v. 8, p. 170-177, 1986. PMid:18925132 PMCid:2547673. http://dx.doi.org/10.1155/S1463924686000330

WOOD, S. G. et al. Seed lipid content and fatty acid composition of three quinoa cultivars. Journal of Food Composition and Analysis, v. 6, p. 41-44, 1993. http://dx.doi.org/10.1006/jfca.1993.1005

WRIGHT, K. H. et al. Composition of Atriplex hortensis, sweet and bitter Chenopodium quinoa seeds. Journal of Food Science, v. 67, p. 1383-1385, 2002. http://dx.doi.org/10.1111/j.1365-2621.2002. tb10294.x 